\title{
Broken words, furious wasps. How should we translate the sonic materiality of Araweté ritual singing?
}

Palavras quebradas, vespas furiosas. Como traduzir a materialidade sônica dos cantos rituais araweté?

Mots brisés, guêpes furieuses. Comment traduire la matérialité sonore des chants rituels araweté?

\section{Guilherme Orlandini Heurich}

\section{OpenEdition}

\section{Journals}

Electronic version

URL: https://journals.openedition.org/jsa/18302

DOI: $10.4000 /$ jsa. 18302

ISSN: 1957-7842

Publisher

Société des américanistes

\section{Printed version}

Date of publication: 30 June 2020

Number of pages: $105-126$

ISBN: 978-2-902715-13-8

ISSN: 0037-9174

\section{Electronic reference}

Guilherme Orlandini Heurich, "Broken words, furious wasps. How should we translate the sonic materiality of Araweté ritual singing?", Journal de la Société des américanistes [Online], 106-1 | 2020, Online since 30 June 2020, connection on 26 September 2022. URL: http://journals.openedition.org/ jsa/18302 ; DOl: https://doi.org/10.4000/jsa.18302 


\title{
Broken words, furious wasps. How should we translate the sonic materiality of Araweté ritual singing?
}

\author{
Guilherme Orlandini Heurich *
}

\begin{abstract}
In Araweté ritual singing, the performance of oporahẽ songs is an exercise in downplaying referential meaning without the actual removal of the sounds of the language. These songs are performed in a way that effectively break words into syllables, which are recombined to form unusual and "meaningless" words. Phrased differently, a good amount of these songs" "meaning" is not in the things to which they are referring. By looking at the effect of this displacement of syllables in the performance and in the written rendering of the Araweté's oporahẽ songs, this paper addresses the role of translation in anthropological practice when referential meaning is not easy to access. Following recent approaches in linguistic anthropology, the paper argues that an attention to the materiality of sound and voice in Araweté ritual singing provides a framework for understanding the performance and translation of songs in indigenous Amazonia. [Key words: voice, materiality, ritual singing, linguistic anthropology, Araweté, Amazonia, Brazil.]
\end{abstract}

Palavras quebradas, vespas furiosas. Como traduzir a materialidade sônica dos cantos rituais araweté? No canto ritual Araweté, a execução dos cantos oporahẽ oculta o significado referencial das palavras mas não remove os sons da língua. Os cantos são executadas de uma maneira que divide as palavras em sílabas, as quais são recombinadas para formar palavras incomuns e "sem sentido". Em outras palavras, uma boa parte do "significado" dessas músicas não está focado no significado referencial. Ao olhar para o efeito deste deslocamento de sílabas na performance e na escrita dos cantos oporahẽ dos Araweté, este artigo aborda o papel da tradução na prática antropológica quando o significado referencial não é fácil de acessar. Seguindo abordagens recentes em antropologia lingüística, o artigo argumenta que uma atenção à materialidade do som e da voz no canto ritual Araweté fornece uma estrutura para a compreensão da performance e tradução de cantos na Amazônia indígena. [Palavras chave: voz, materialidade, canto ritual, antropologia linguística, Araweté, Amazônia, Brasil.]

Mots brisés, guêpes furieuses. Comment traduire la matérialité sonore des chants rituels araweté ? Dans le répertoire des chants rituels araweté, l'interprétation des

* Department of Anthropology, University College London, London, United Kingdom [g.heurich@ucl.ac.uk]. 
chants oporahẽ est un exercice de minimisation de la signification référentielle sans suppression réelle des sons de la langue. Ces chants sont interprétés de manière à diviser les mots en syllabes, lesquelles sont recombinées pour former des mots inhabituels et « sans signification ». En d'autres termes, une bonne partie du « sens » de ces chants ne se trouve pas dans ce à quoi ils font référence - la signification référentielle n'est pas leur centre d'intérêt. En examinant les effets de ce déplacement de syllabes dans l'interprétation et dans la transcription des chants araweté, cet article aborde le rôle de la traduction dans la pratique anthropologique lorsque le sens référentiel est difficile d'accès. Suivant des approches récentes en anthropologie linguistique, l'article montre que l'attention portée à la matérialité du son et de la voix dans les chants rituels araweté fournit un cadre pour comprendre la performance et la traduction des chants en Amazonie. [Mots-clés : voix, matérialité, chant rituel, anthropologie linguistique, Araweté, Amazonie, Brésil.]

In the Araweté village where I conducted fieldwork, music was a constant presence. Shamans sang in almost daily ritual context, men sang war songs collectively at parties, but people also constantly listened to recordings of these songs and repeated their melodies while doing all sorts of chores. My interlocutors talked about these songs at night after the evening meal, sometimes instigated by my questions, but often without my encouragement. As well as these moments, however, my research into Araweté singing practices included time dedicated to listening, transcribing, and translating songs. In this regard, Irarũno Araweté was the person with whom I collaborated the most, doing everything from translating lullabies, listening to shamanistic songs, and transcribing the most challenging ones called oporahe.

The Araweté are 500 maize cultivators and hunters who live in Eastern Amazonia in seven villages in the Brazilian State of Pará. They have been in contact with Brazilian government representatives since the late 1970s and most of them currently speak Portuguese, even though they only communicate with each other in Araweté, a Tupi-Guarani language. I conducted 14 months of ethnographic fieldwork with the Araweté between 2011 and 2014, returning briefly in 2015 and 2017. At the start of the rainy season in 2013, Irarũno and I frequently got stuck in the process of deciphering the words in the recordings of Araweté's oporahẽ songs. Even though both of us had taken part in the performance of these songs just a few weeks earlier, it was difficult to distinguish one word from another. It certainly sounded like the Araweté language, but we simply could not tell what was being sung. The sung words sounded like random combinations of syllables taken from actually existing words, as if words in the language had been broken into parts, then recombined to form senseless new ones.

The problems we faced while listening to the recordings of the oporahe were different from the difficulties we had encountered while transcribing recordings 
of other musical genres of the Araweté. The problem was not speed since the oporahẽ are sung at a slow pace - and neither was it the length of the songs since the performance of the oporahe consists in the repetition of a few verses for several minutes only. The problem, as we later discovered, was that the morphemes each word consisted of seemed to have been shuffled around, disturbing the expected order.

One late afternoon at Irarũno's house, as we tried to decode a song, an older man called Aritãi'no walked in, stopped for a moment to listen, and then spelled out the song for us by singing the whole verse a few times. Aritã'ino then looked at both of us, smiled, and quickly left the house. "He puts it swiftly" (huamuñe $k u$ wĩ umarã), said Irarũno, suggesting that the man's experience in singing these songs was crucial to decode the words, to "put" songs into words so fast. However, if Irarũno and I were faced with "broken words" that initially sounded very difficult to transcribe, this obstacle later became a window of opportunity. While reworking these transcriptions away from the field, I suddenly realized that they allowed for an interesting experiment in translation. Unsure whether to use breathing patterns or a trochaic foot to distinguish each line of the song, I kept exploring different possibilities of the written form. Eventually, it became clear that, however the lines were parsed, there was something more important going on in these songs. I came to realize, finally, that a good amount of the songs' "meaning" was anywhere but in the things to which they were referring. In this regard, the performance of the songs seemed to be an exercise in downplaying referential meaning without the actual removal of the sounds of the language. They were phonological icons of the Araweté language.

The way the songs were performed-effectively breaking the words into smaller syllables, which were then recombined to form unusual and apparently meaningless words - could be transposed into written form. And thus, Irarũno's and my initial transcriptions could be transformed from a comprehensible rendition of words to a distinctive, yet almost unreadable, collection of syllables. By looking at the effect of the displacement of syllables in the performance and in the written rendering of the Araweté's oporahẽ songs, this paper addresses the role of translation in anthropological practice when referential meaning is not easy to access. Following recent approaches in linguistic anthropology, the paper argues that anthropology can benefit from looking at the material wrapping of words - the materiality of sound and voice - in Amazonian ritual singing.

\section{Anthropology, materiality, and translation}

Translation has increasingly been the object of attention in anthropology. Hanks and Severi (2014), for example, recently suggested that translation is at the heart of anthropology and that "ethnography, from a theoretical point 
of view, is unimaginable without translation" (ibid., p. 6). They argue that translation goes beyond the task of literal translations, for ethnography is about transforming descriptions and theories that belong to a specific place into the language of a scientific community. As such, it is a demanding and difficult enterprise, for "even the simplest lexical translation is multidimensional," and "when we move to pragmatically enriched utterances, the task becomes astronomically difficult" (ibid., p. 7).

Perhaps because translations are not simple "word-for-word matchings" (Gal 2015, p. 231), anthropologists reflecting on the subject have emphasized how they are, ultimately, imperfect (Herzfeld 2003). Rendering a narrative, speech, or song of a different language into one's own (or into another language) is nothing more than the systematic recommencement of repeated acts of failure (Ciardi 1961). In a recent analysis of Navajo poetry, for example, Webster (2016, p. 13) argues that "no two languages share the same sound and sense configuration" and that discussions about translation should include an acute attention to the "muscularity and physicality of language" (ibid., p. 14) —what Harkness (2014, p. 10) calls the "phonosonic nexus" of the human voice. ${ }^{1}$ Since the phonetic wrapping of words is not shared by any two languages, "we must take seriously the phonetic clothing - the sounds - of languages and the imaginative work such clothing allows and inspires" (Webster 2016, p. 35). In other words, taking what people say seriously can thus include contemplating seriously how they sound.

In an attempt to account for rhymes in Cretan poetry, for instance, Herzfeld replicates the line-ending assonance of the original poems in his own translations of them:

\section{pigha ke proskinisa s' ena erimoklisi, \\ k' idha ti Mana tou Khristou ya mena na dhakrizi.}

I went and found a lonely church and prayed on bended knee! and I beheld the Mother of God as she shed tears for me. (Adapted from Herzfeld 2003, p. 125: my emphasis)

The author recalls how he took this translation to a "well-known poet and translator of modern Greek literature," who told him that "these were doggerel, the Greek originals were not." Discouraged by this critique, he took his poems away and "never tried to inflict them on anyone else" (ibid., p. 126).

1. Harkness" idea of a "phonosonic nexus" is a conceptual attempt to "analyze systematically two important facts: that the voice concerns both sound and body, and that it links speech and song" (Harkness 2014, p. 12). Several anthropologists have recently taken up the voice as an analytical theme (Feld et al. 2005; Kunreuther 2014; Weidman 2006), perhaps attempting to overcome a distinction between language and music, as has long been suggested by linguistic anthropologists and ethnomusicologists (Seeger 1986; Faudree 2012). 
As an attempt to relate between sounds of the spoken word and the written form, translations are provisional devices that foreground the sonic materiality of the human voice and, also, that highlight how these sounds parallel or index specific social relations. As such, an anthropological reflection on the translation of the spoken word is not only relevant to anthropologists working with poems, songs, and other forms of vocal art. It is also relevant to any experience in writing anthropology (Rapport and Nielsen 2017), where sound and sense can be jointly looked at. Since translations have historically underrepresented the sonic materialities of the spoken word (Meschonnic 1999, 2008a, 2008b), there is still a long way to go in order to understand how paying attention to sounds affects the provisional and relational qualities of translations, and, furthermore, how looking at the physicality of sound, the rhythm in translation, shows how specific theories of language - such as the Western focus on referentiality-have shaped the way in which we have translated so far. ${ }^{2}$

In translation studies, there are traditionally two ways of relating to a source text or language: either the original language is "domesticated" or the target language is "foreignized" (Venuti 1995). Briefly, domesticating is the idea that one should benefit the reader by changing the putative referential or literal meaning of the original to better fit with the language into which one is translating, whereas foreignizing tries to focus on the author by keeping as many features as possible of the original — even when this means sacrificing some qualities of the language we are translating into and thus eschewing any concern with the reader. Leavitt (2014) argues that the second approach, making it "foreign," sometimes results in translational "monstrosities"-which he thinks are positive. In his own work on the translation of Kumaoni poetry, the author addresses these questions when asking whether it is possible to maintain in the text "some of the qualities of a performance that has rhythmic, dynamic and melodic dimensions" (ibid., p. 210). For him, the choice of translation thus derives not only from the particular rhythmic aspect of these songs but also from the relations that are explicitly conveyed during ritual action. ${ }^{3}$ In other words, the relational rhythm of the spoken word affects the written word, and the relations expressed during the performance are equated with the relations between words.

2. Listening to the sound of words does not need to be exclusive to the spoken word. It can be used to highlight the rhythm of a language, for example, when dealing with the translation of texts. See, for example, Meschonnic's (1999) discussion of different translations of the Bible, all of which imposed a Greek "order of the sign" —or "order of meaning"—onto the original Hebrew.

3. "The choice of transcription using clauses separated by commas rather than, say, imposing a standard sentence-structure, involves a preliminary analysis of the relations among the participants in the ritual: that the singer is singing to gods and ancient gurus, that the audience is there as privileged overhearers" (Leavitt 2014, p. 212). 
The oporahẽ songs that Irarũno and I translated were performed in 2013, but learned by the Araweté a long time ago. These songs originated in a conflict that occurred 30 years before when the Parakanã, a contemporary neighbouring Amerindian group but then still un-contacted by Brazilian authorities, attacked the Araweté village in the upper Ipixuna river in 1983. Amongst the Araweté, oporahẽ songs originate in such skirmishes with non-Araweté peoples, where any victim from conflict - a killed or simply shot enemy - will teach songs to his killer; more specifically, songs that the victim's "soul" or "double" (a'owe) teaches to his killer. ${ }^{4}$ These songs are descriptions of scenes that his victim's double saw and heard on his journey to the "end of the world" (iwã neji pã) and back. Each song is an impression or depiction of a scene, filled with intricate meanings concerning its actors and actions. The songs are, from time to time, performed in a ceremony fuelled by maize beer that lasts as long as the beer does-usually between 24 and 30 hours. $^{5}$

\section{Setting the stage for the songs}

It was early evening, and my initial idea was to record the performance of the Araweté's oporahe from afar, sitting next to a house that encircled the patio. Irarũno sat with me while we drank large gourds of maize beer and soon suggested that I should go dance with the men as well, from where I could record the songs better.

Before the ceremony, everyone is scattered around the patio, lying on mats by small bonfires, perhaps being fed some beer, smoking, or just resting. The collective of singers is assembled just minutes before the actual performance takes place. The singers do not come as a group from a different part of the village and then enter the patio - they do not walk on the stage, so to speak. When the main singer, called maraka' $i$, stands up from his mat and walks towards the centre of the patio, all the men who want to sing follow him. Some will position themselves directly beside the main singer and interlock their arms with him, while others will either stand behind him (and interlock their arms with other men) or stand in front of him (and interlock their arms with other men). The final composition of

4. Similar songs can also be learned from a couple of animal species that are infrequently shot by the Araweté. Only the howler monkey and the jaguar are considered to teach songs, for they are thought to be "like us" (bide herĩ), and are thus treated as "enemies" (awĩ). From them the Araweté learn songs, which are then performed as an oporahe, with the same effects of "broken words," although without beer drinking. In this regard, howler monkeys and jaguars are treated as victims of warfare in a similar way to when a non-Araweté person is killed.

5. Several authors have described drinking parties among Amerindian groups in Lowland South America, including early chronicles and reports from 16th- and 17th-century missionaries (Léry 1580; Montoya 1639; Staden 1974 [1557], to name a few), and also recent ethnographic descriptions (Lima 2005; Sztutman 2007; Vilaça 1992; Viveiros de Castro 1992). 
the collective is a compact formation of rows of three to four men each, and the central row is the one occupied by the main singer. The collective is nameless, there is no word for it, but one should imagine a military column in which men are very close to each other. Being warfare songs, as these are, the image seems appropriate. The men all face forward, their arms interlocked with their neighbours on their side, and each holds a bow or an arrow (or both) in one or both hands.

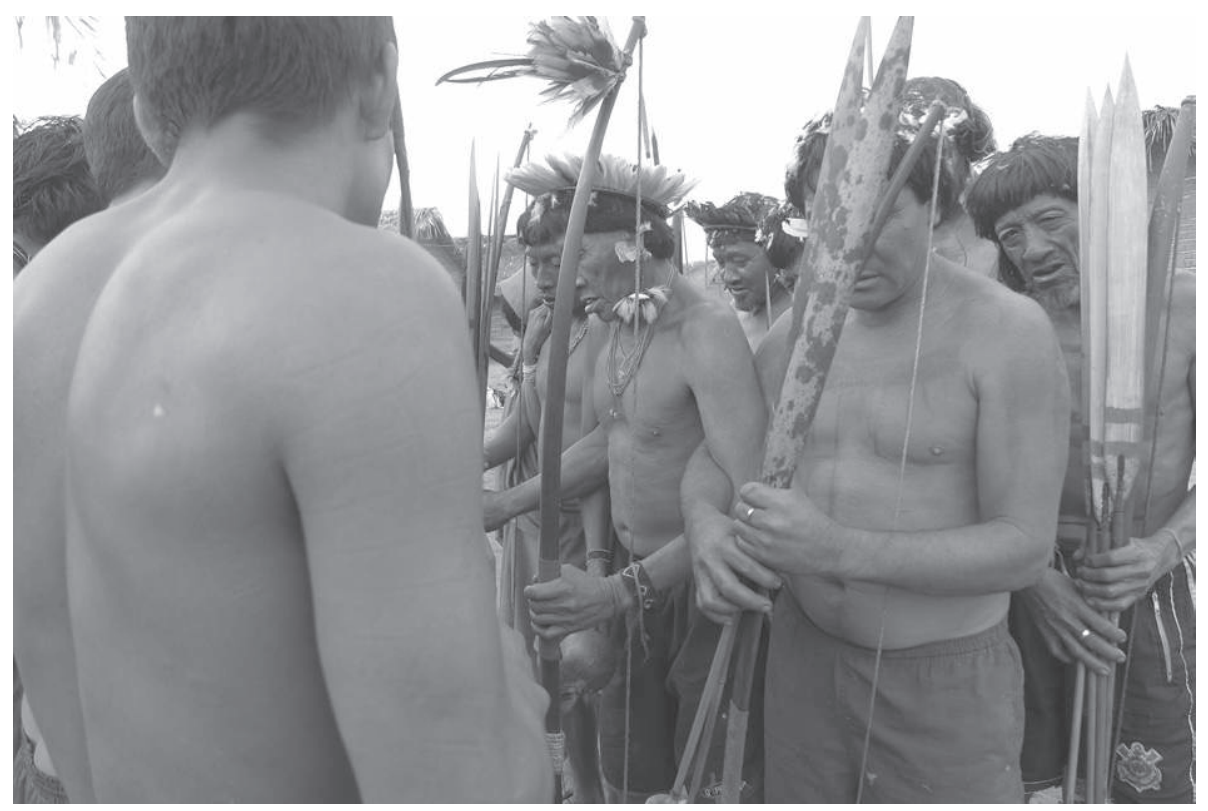

Fig. 1 - Oporahẽ at Paratatsi village (photo Camila Caux, September 2013).

There are, in fact, two main positions in the collective of singers - the "singer" (maraka'i) and the "prompter" (memo'o hã)-occupied, respectively, by Moiwerã and Heweyero on this occasion, both of them quite senior Araweté men, around 70 years old. Maraka' $i$ refers to the small gourd rattle (maraka) that the singer carries and plays during the ceremony, while memo'o hã is a nominalized form of the verb memo'o, meaning to "tell" or "teach." I have chosen to translate it as "prompter" to evoke the memo'o hã's way of singing during the ceremony. He sings the lines of the song a micro-second before the singer, thus prompting the singer to do the same.

Singer and prompter are the only two roles that are established before the actual party takes place, and the only requirement for these roles is that the "prompter" must be someone who knows the songs, ideally someone who has killed an enemy before and therefore learned the songs directly from his victim. 
However, since these songs can be given to someone else, the "prompter" can be someone who acquired these songs during his lifetime without ever participating in any skirmishes. Since the roles of singer and prompter are the only two roles decided before the party, and because these men are the leading figures in this event, they are the first ones to approach the courtyard and it is around them that everyone else will find a position. These positions are not previously arranged and are decided in a playful and on-the-spot manner.

Most men will voluntarily join the collective of singers, but some might have to be exhorted to participate into participating. When the men were positioning themselves during the oporahẽ of 2013 to start singing, an Araweté mother urged her son to be a part of the ceremony. She encouraged her son to come and position himself as the "singer's opposer" (maraka'i penowã ñ̃a) and several other men used variations of this expression to support her call.

\section{Example 1}

Woman

Man 1

(1) howapi jiwãne

h-owapi jiwã-ne

3-to.close $\quad$ arm-REL ${ }^{6}$

close (the row) with your arm

(2) peja howaña ti

pe-ja h-owa-ñã ti

2IMP-to.come 3-face-owner LOC

come, to face your opposer

Woman

(3) peja howañã nerowãpi mu

pe-ja h-owa-ñã ne-rowãpi mu

2IMP-to.come 3-face-owner R-to.close TRANS

come, to become who closes and faces your opposer

Man 2

\begin{tabular}{|c|c|c|}
\hline peja & maraka'i & rowã̃̃a \\
\hline pe-ja & maraka'i & rowã-ñã \\
\hline 2IMP-to.come & singer & R-face-owner \\
\hline
\end{tabular}

6. Linguistic conventions used here follow Solano's (2009) grammatical description of the Araweté language, and are as follows: REL, relative case; IMP, imperative; LOC, locative; TRANS, transformative; FOC, focus; R-, relational particle; CC, comitative. All the letters should be pronounced like in Brazilian Portuguese (BP), except the $\dot{i}$, which is a closed central unrounded vowel that should be pronounced as a BP "u" with the mouth shaped like a BP "i." 
The young man's mother tells him to close (howã pi) the row by interlocking his arms (1) and a man echoes her call by exhorting him to come and stand in front of the "face owner" (2), which I translated as "to face your opposer." The notion of "opposer" or "contrary" is crucial here and several authors have looked into it in the Tupi-Guarani context, mainly by exploring the Tupinambá notion of tovajar - a word that means both "enemy" and "brother-in-law" (Clastres 1972; Carneiro da Cunha and Viveiros de Castro 1985; Sztutman 2007). I note that a similar expression is used here to describe the "owner" ( $\tilde{n} \tilde{a})$ of one's "face" (rowã, e.g. "he rowãa," my face): h/rowã ñã. Following the authors mentioned above, it is possible to say that it is not an expression that only denotes any person who is in front of you - who owns your face, who looks at you-for it evokes the whole context of the ceremony, that is, warfare. It is in this context, then, that the young man is to come and be the one who "closes and faces your opposer" (3), that is, "to face the singer" (4). However, since the singer himself sings from the point of view of the enemy, a singer's opposer-such as this young man-does not represent the enemies, but the Arawete themselves.

\section{Voice and body: the performance of the oporahe्e}

After assembling all the singers who will take part in the ceremony, singing can finally begin. At the start of a song, the "prompter," who knows the song, and others who might have sung it at previous parties or heard it in recordings, take the lead and the others follow as well as they can, trying to keep it in unison. When performing the oporahe songs, the ideal is to sing in unison. However, unison is achieved gradually during the performance and not immediately from its outset. In other words, singing the oporahe is not a choir-like performance in which all the voices start and stop at the same time. Since there is no rehearsal, unison is achieved not by training but during the performance itself of each individual song.

Since the songs are very short - usually a few lines - and are repeated over and over for anything between 20 and 40 minutes, there are plenty of opportunities to synchronize one's voice with the others. Every time another loop starts, there is a chance to join in. In the track below, we can hear the moment in which another man joins in-his low-pitched voice is distinctive.

\section{Example 2: Gradual Unison ${ }^{7}$}

Each song always starts in a low volume, always starting in a low volume that increasingly builds up strength until it abruptly stops. Between each song, people

7. The reader is advised to listen to the recordings that accompany this article while following the examples. First listen here "Audio 1 - Extract from Song 11 of the oporahe at 
go back to their mats, relax, smoke, drink beer, and rest for 15 to 20 minutes before returning to the patio. Every time a different song is sung, the voices pull together in unison. The singer stands up from his mat, where he has stayed with his wife and children while resting between the songs. The prompter follows him to the courtyard and stands behind him, and then the rest follow. At the same time as they start singing, the group immediately starts moving slowly in a counter-clockwise direction in the courtyard. A compact group of men, all of them facing forwards, with their arms interlocked, move their right foot forward and slowly drag their left foot in sequence. The right leg straightens, stretching the back muscles of the leg and lifting the whole body up. The left leg moves forward as if it were a crutch or stilt, and immediately the body enters partial rest: the right relaxes, the upper body moves downwards. The right leg takes a step forward, straightens again, and the movement starts one more time.

In a similar vein to the "catch-up" process that occurs in each song-men trying to follow and jump into the unison singing - men try to synchronize their steps with those in front of them. These two processes are pretty much the same process. Here, singing in unison and moving in coordination are joint processes in dance. It is ultimately impossible to separate body and voice in the performance of the oporahe, because every time the right foot moves forward, one or two syllables are uttered, and every time the left foot accompanies, another one or two syllables are uttered. From an analytical perspective, this is an important aspect of these songs: each step of the body follows the voice-each verse of the voices follows a step.

\section{Broken words: sonic materiality in the oporahe्e}

For the Araweté, my work as an anthropologist consisted in producing "designs" (ikuxã) on paper of everything they told me. Not only because I was constantly taking notes, but mainly because of the hours of attentive listening, transcribing, and translating with Irarũno, Irarũhi, and Irarũ, to which I would dedicate myself every two days or so. Either at my house or at theirs, Irarũno and I would listen to songs, put them down on paper, and attempt to translate them with the solid advice of his wife, Irarũhi. For his part, their two-year-old son, Irarũ, was quite happy to remain on the floor, scribbling designs on paper with some pencils.

As I mentioned at the beginning, the initial way in which Irarũno and I translated these songs didn't do justice to the way in which they are actually sung. Initially, I was unable to account for the fact that, during the performance of these

Paratatsi village (September 2013, 22 secondes)", https://www.nakala.fr/data/11280/4f602cec (last access, 15/06/20). 
songs, the interval between words changes and moves "inside" the words - so to speak - spreading the syllables into words that have a regular sound structure.

\title{
Example 3
}

$\begin{array}{lll}x \tilde{a} & k u & \text { tapi’okã } \\ \text { xã } & \text { ku } & \text { tapi'okã } \\ \text { Look } & \text { FOC } & \text { wasp } \\ \text { wasps become } & \end{array}$

\author{
uñarã neropitã \\ u-ñarã n-ero-pitã \\ 3-angry R-CC-stay/become \\ furious here
}

Song 1 - "The furious wasp"

Our initial rendition, in Example 3, does not take into account that the performance "breaks" or "cuts" the words of these songs. It was only after fieldwork that I realized how I could combine the translations of the oporahe with the movements of the dance and the collective singing. I would have to rework the translations, trying to think of a way of cutting the syllables in the moment in which the legs move and respecting the breathing patterns. More importantly, the fact that it was conceivable to do it suggested that singing, moving, and writing could be in coordination. As such, they would become different scales of a similar process.

In the following pages, I will draw repeatedly on "The furious wasp" song, reshaping it as I discuss each possibility to foreground the material quality of Araweté ritual singing. The first attempt consisted in placing the syllables together with the movement of each leg. I designed each syllable or pair of syllables in coordination with the movement of the right foot (RF) or the left (LF).

\section{Example 4}

$\begin{array}{cccccccc}\mathrm{RF} & \mathrm{LF} & \mathrm{RF} & \mathrm{LF} & \mathrm{RF} & \mathrm{LF} & \mathrm{RF} & \mathrm{LF} \\ x \tilde{a} & \boldsymbol{k} \boldsymbol{u}-\boldsymbol{t} \boldsymbol{a} & p \dot{\prime} \prime o & k \tilde{a} & u \tilde{a} a & \boldsymbol{r a}-\boldsymbol{n} \boldsymbol{e} & \text { ro-pi } & \text { ta } \\ \text { Look } & \text { FOC-w } & \text { as } & \mathrm{p} & 3-\mathrm{an} & \text { gry-R } & \text { CC-re } & \text { main } \\ \text { wa } & \text { sps } & \text { be } & \text { co } & \text { me } & \mathbf{f u} & \text { rious } & \text { here }\end{array}$

Song 1 - "The furious wasp"

8. Secondly listen here "Audio 2 - Extract from Song 6 of the oporahẽ at Paratatsi village (September 2013, 23 seconds)", https://www.nakala.fr/data/11280/a67baa36 (last access 15/06/20). 
Two examples from the song above show how the space between words is not in the place that the Araweté language usually puts it. The tapí 'okã wasp, for instance, is not only split into ta, pito, and $k \tilde{a}$ but is also regrouped into other syllables to compose new words - such as kuta, highlighted above in bold. The vocable rãne, also highlighted above, is another unusual composition of syllables, for it takes the final syllable of the verb uñarã and the first syllable of the verb neropitã. Rãne does not mean anything in Araweté; it is not a word, it is not a metaphor. It is, rather, the obvious consequence of rhythmic patterns of the dance on the voicing of words.

The separation between syllables is also visible in a spectogram ${ }^{9}$ of the initial nine seconds of Audio File 2. The image below shows one complete verse of the song above, and there are two relevant elements in it: the silences between each syllable and the respiratory breaths of the singers.

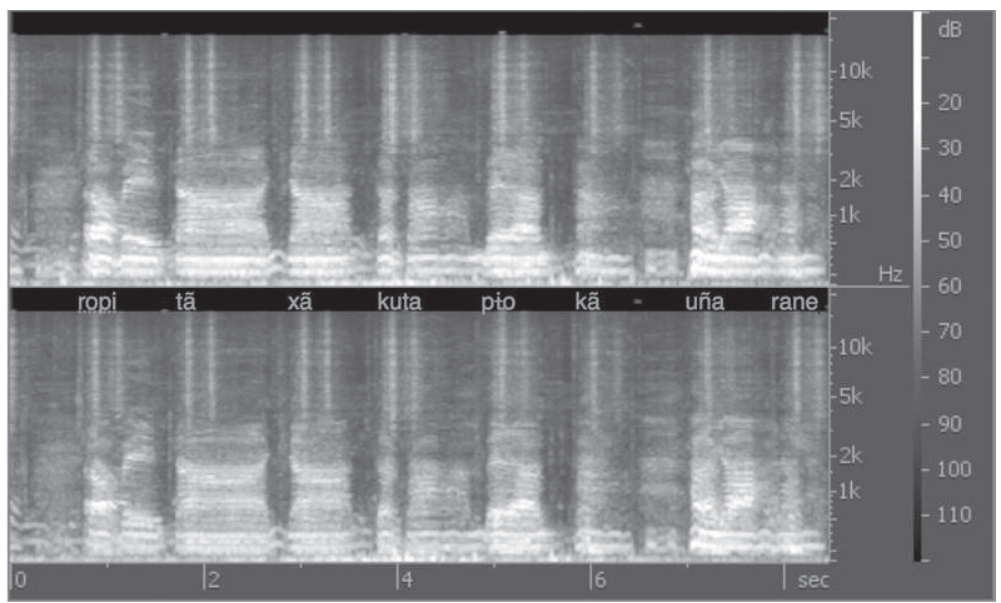

Fig. 2 - Spectogram of Song 6 of the oporahẽ at Paratatsi village (G. O. Heurich, September 2013).

A spectogram graphically shows how high, in decibels, a sound is - the brighter, the louder. Figure 2 (above) presents bright orange (or brighter in white and black view) areas when the singers utter the syllables (written in the middle line) and also darker areas just before them, which indicate lower sounds or silences. It is a visual depiction of the oscillation between sounds and silences, which fits with the attempt, in Example 4, to render this song in written form.

Additionally, the spectogram highlights something else: the order of syllables in the red caption is not the same as the order presented in Example 4. While

9. The spectograms are a three-dimensional analysis that includes the time (abscissa), frequency (ordinate), and the quantity of energy in decibel (colour or thickness of the lines). 
the latter starts with "xã kuta...," the former's initial syllables are "ropi tã." In Example 4, the order of the sentence is written as it would make sense in Araweté-with the exhortative expression xã ("see," "look," "here") at the beginning - while in the spectogram, this expression is preceded by "ropi tã." Thus, "ropi tã," the second part of the verb neropitã, is not at the end of the stanza but at its beginning.

Arguably, a spectogram is not a depiction of any "reality" but a tool with which to visualize sonic structures that would otherwise be rather difficult to perceive. Here, it allows me to give a visual rendering of something that I realized after hours of listening and analysing oporahe songs: the rest between syllables is longer inside a verse than between verses. In this particular example, the rest between "rãne" and "ropi" is longer than the rest between "tã" and "xã." Since longer rests in other genres of Arawete ritual singing, and, arguably, in most verbal art forms, tend to precede a verse, what the oporahe seem to do is place the rest in the middle of the verse. However, instead of presenting this rest as a long space in the middle of the verse, my choice was to turn this rest into the "actual" beginning of the verse.

As such, the spectogram emphasizes not only how the words in these songs are "broken," but also how the verse, as a whole, is broken: that is, it does not start when an ordinarily constructed sentence would. Here, the spectogram is a neat visualization of the benefits of thinking through the materiality of the voice in ritual singing. By temporarily suspending an attachment to the syntactic structure of a sentence in Araweté - in which an exhortative such as "xã" is on the leftmost area of the sentence- the analyst can foreground the sonic structures of Araweté ritual singing.

In the light of this, would it be possible to re-arrange the transcription and translation of this song? Such is the attempt made below in Example 5. Here, the verb neropita - in bold, below - is split: the /ne/ joins /rã/ to form /rãne/ and the rest of the word is left by itself, but it is moved to the beginning of the verse. In other words, the ropitã that is "missing" from the end is at the beginning of the verse. In doing this, transcription and translation are directly affected by the sonic shapes in this song.

\section{Example 5}

$\begin{array}{cccccccc}\mathrm{RF} & \mathrm{LF} & \mathrm{RF} & \mathrm{LF} & \mathrm{RF} & \mathrm{LF} & \mathrm{RF} & \mathrm{LF} \\ \text { ropi } & \text { tã } & \text { xã } & \text { kuta } & \text { pi’o } & \text { kã } & \text { uña } & \text { rãne } \\ \text { CC-re } & \text { main } & \text { Look } & \text { FOC-w } & \text { as } & \text { p } & 3 \text {-an } & \text { gry-R } \\ \text { rious } & \text { here } & \text { wu } & \text { asps } & \text { bee } & \text { come } & & \text { foo }\end{array}$

Song 1 - "The furious wasp" 
However, there is more, for their re-arranging uncovers something else. Given that verses can be repeated over and over for half an hour or more, the split verb neropitã, in fact, connects one verse to the next one (i.e. the repetition). The movement of part of a word to the beginning of the verse prompts the verse to loop. The last part of neropitã is at the beginning of the next verse. That is, the last part of a word is in the next verse, but then it is in the next one again, but then it is in the next one again...

\section{Example 6}

$\begin{gathered}\ldots \text { rãne }] \\ \text { previous verse }]\end{gathered}$
ropi tã xã kuta

Song 1 - "The furious wasp"

The third relevant aspect in Figure 2 is the slightly longer patches of silence before the syllables "ropi," right at the beginning, and closer to the end, before the syllables "uña." These are the breaths that singers take while singing this verse, and this breathing pattern was something that I also wanted to introduce in the written form of the oporahe्.

\section{Example 7}

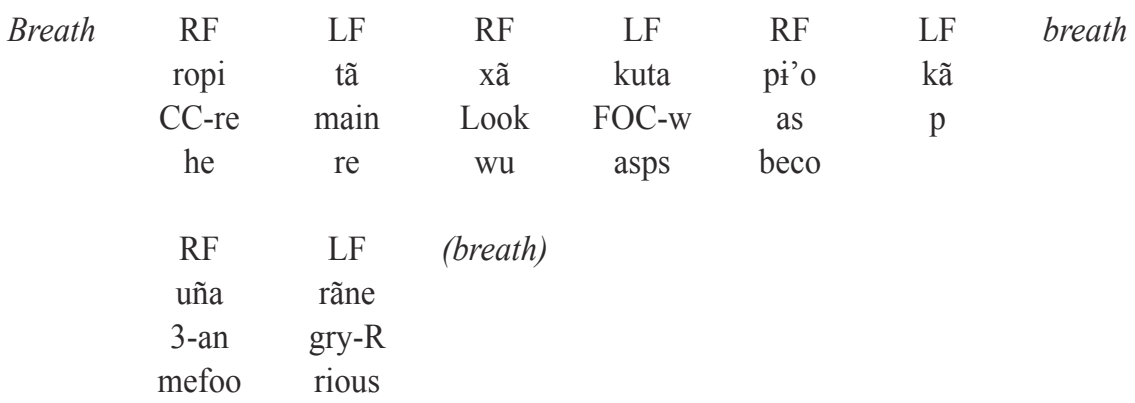

Song 1 - "The furious wasp"10

Finally, we can extract the original verse and the translation from the work of reshaping them:

$$
\begin{array}{ll}
\text { ropi tã xã kuta pìo kã } & \text { rious he rewu asps } \\
\text { uña rãne } & \text { beco mefoo }
\end{array}
$$

10. Listen again here "Audio 2 - Extract from Song 6 of the oporahẽ at Paratatsi village (September 2013, 23 seconds)", https://www.nakala.fr/data/11280/a67baa36 (last access, $15 / 06 / 20)$. 
The example above is an attempt to translate "The furious wasp" in a way that takes into account the sonic materiality of Araweté ritual singing. All the elements described before-feet movements, broken words, broken verses, and breaths - are included in one depiction of this song in written form. The next step, of course, is putting all of this together in translation, but since translation also needs to include the referential elements of meaning-what these songs are about - it is still not clear if the displacement of syllables in the examples above parallels the lexical meaning of these words. How do the sonic and performative dimensions of these oporahe songs relate to the semantic meaning of their words?

\section{"The fleeting nightjar" and "The furious bumblebees"}

In our sessions of transcription and translation, Irarũno would frequently say, "Irarũhi put it correctly" (umarã hete ku Irarũhi), whenever his wife, Irarũhi, offered an alternative word or sentence to what he had initially suggested. He expressed himself in a similar manner when he commented on Aritai'no's swiftness of understanding oporahẽ songs — at the beginning of this paper — by saying, "He puts it swiftly" (huamuñe ku wĩ umarã). On the one hand, oporahe songs modify silences between words, displacing syllables as they do so. On the other hand, translations are, as Irarũno says, a matter of putting (marã) words in the correct (hete) place.

Aritãi'no's swift placement of words allowed Irarũno and me to explore and decode the rest of that recording and the rest of the songs. It gave us the key to understanding how the silences between words were placed inside the words themselves. It allowed us to understand how syllables and silences were placed and displaced in the oporahe songs, such as in the following examples of two other songs.

$\begin{array}{ll}\text { mopo iye kanope pare heye } & \text { frond a plew miss of ahoy all hawk } \\ \text { akurã ñojo } & \text { a night jar-fly ez }\end{array}$

Song 2 - "The fleeting nightjar"

Or, keeping the sentence structure:

\begin{tabular}{|c|c|c|c|c|}
\hline kапорера & rehe & ye & akurã̃̃o & ојоторог̃ \\
\hline kano-pepa & rehe & ye & akurãño & o-jo-mopoĩ \\
\hline harpy-feathers & R-REL & INT & nightjar & $\begin{array}{l}\text { 3-REC- } \\
\text { stand.up }\end{array}$ \\
\hline
\end{tabular}


hãne heye mama ñãnã rãnot lee annas bumble bees are foo rious iña tsimu bee cause of our

Song 3 - "The furious bumblebee"

Or, keeping the sentence structure:

$\begin{array}{lllll}\text { iña tsimuhã } & \text { nehe } & \text { ye } & \text { mamañã } & \text { nãrã noì } \\ \text { iñatsimuhã } & \text { n-ehe } & \text { ye } & \text { mamañã } & \text { nãrã-noł } \\ \text { lianas } & \text { R-REL } & \text { INT } & \text { bumblebee } & \text { furious-? }\end{array}$

bumblebees are furious because of our lianas

In "The fleeting nightjar", a nightjar flies from the plumes of a royal hawk. "Plumes of a royal hawk" is a figure of speech that designates the whole by one of its parts and it refers to the arrows, which have royal hawks' tail feathers attached to their ends, ${ }^{11}$ used by the Arawete in warfare and hunting of large game. From them - because of them, in relation to them - moves the nightjar, a bird known by the Araweté as akurã . ${ }^{12}$ Briefly, the song describes a scene where a nightjar flies away from the arrows being shot at him. According to my interlocutors, this is a description of the original skirmish that led to the demise of one Parakanã man, whose "double" (a'owe) taught songs to the Araweté killer. However, the scene is an inverted mirror, for the attackers are the Arawete (and their royal-hawk feathers) and the attacked the Parakanã, precisely the opposite of what happened in 1983. In this scene, the Parakanã victim is associated with the nightjar: he is the one trying to escape the arrows of the Araweté, but who eventually dies.

As Aritai'no once told me, the nightjar "names" (papa) the victim's soul. As he phrased it, the nightjar is the "name-giver" (papa hã) of the "enemy's double" (awĩ na'owe). ${ }^{13}$ This relationship between a namesake and a name-giver also appears in other songs, where the victim's soul is associated with other

11. Known in Portuguese as "Royal-Hawk" (Gavião-Real), the harpy eagle (Harpia harpiya) is a large predatory bird that lives in the lower portion of the forest canopy. It is central to many Amerindian mythologies and rituals, and its feathers are commonly used as body adornments.

12. The nightjar is a bird from the Caprimulgidae family, found pretty much all over the world. It flies at night and tends to remain on the ground for long periods, where it also builds its nest. It is a central character in Lévi-Strauss' fifth book on Amerindian Mythology (LéviStrauss 1988), where it is associated with the art of pottery and also with conjugal jealousy.

13. -papa is the verb "to name" something or someone, whereas $h \tilde{a}$ is a derivational suffix that transforms a non-noun into a noun. Since this specific suffix, according to Solano (2009), carries an agentive aspect, it takes a verb and makes it into an agent, thus "to name" (papa) becomes "name-giver" or "namer" (papa hã). 
beings. Following Aritai'no's phrasing, we could say that the victim's soul is named by these other beings: the wasp tapi 'okã in "The furious wasp" (Song 1) and, similarly, the bumblebee mamañ ã in "The furious bumblebee" (Song 2).

We can understand this relationship between namesake and name-giver as a metaphorical relationship, where nightjars, wasps, and bumblebees are, in fact, metaphors referring to victims' souls. ${ }^{14}$ In "The furious bumblebee", for example - perhaps one of the most obscure in the whole set of songs performed in September 2013 - the bumblebee is furious because of "our lianas." The bumblebees (mamã̃̃̃a) are furious, Aritai'no told me, because they get caught in lianas (iñatsimuhã) that hang from the forest trees, and the lianas are an allusion to the killer's hair-“our long hair" (ure ã woko), as Aritai'no phrased it - which infuriates the victim's soul. ${ }^{15}$ Wasps, bumblebees, and nightjars are, here, used to stand in the place of the victim's double. However, the oporahe songs are sung from the victim's double's point of view. In this case, why would the victim use such an indirect way of talking about himself? Why would the victim resort to metaphors to describe scenes which he witnessed himself?

Viveiros de Castro's (1992) analysis of the Araweté's oporahẽ songs focused, precisely, on the reflexive properties of reported speech and its use by the killer and the victim. Briefly, he shows how these songs create a "fusion of perspectives" between killer and victim in which citations within citations form a layer of indiscernible points of view, blurring the distinction between self and other, making the victim an inextricable part of the killer. His analysis, however, does not account for the displacement of syllables that occurs during the songs' performance, which I argue is one of the most relevant and striking characteristics of the Araweté's oporahẽ. If that is the case-if the broken words of the oporahe are crucial to understanding these songs-how would that change the way in which we analyse sound and music in Amerindian verbal art?

The interplay between self and other has been one of the most fruitful conceptual tropes in the anthropology of Amazonia, and a big part of it started, precisely, with the interplay between Arawete killers and their victims. Therefore,

14. Without addressing the many issues around the concept, metaphor can be defined as a process or act in which "a term that routinely stands for one thing or kind is made to stand for another," and "the effect is to transfer the term in question from its accustomed place in our verbal classificatory scheme to some other unaccustomed place for special temporary expressive purposes" (Hills 2017).

15. I was unable to fully grasp why or in which moment the victim's soul gets furious with "our long hair." Referring to a similar allusion in a different song, Viveiros de Castro argues that " $[\mathrm{t}]$ he spirit of the enemy alludes to his condition as a corpse: beetles and bumblebees alight on his putrefying body, [...] it refers to the hair of both the dead man and his killer, beings who are interwoven, so to speak, like the locks of hair in this song" (Viveiros de Castro 1992, p. 245). It is likely that this also refers to what stingless bees typically do when someone disturbs their nest. 
exploring the ways in which dance, rhythm, breathing, and movement provide us with another layer of comprehension of the oporahe songs, this article not only contributes to the development of long-standing anthropological conceptssuch as the relationship between self and other-but it does so by shining a light into a dimension that has so far been overlooked in the scholarship of the region, that is, language. In doing so, it disrupts the centrality of referential and metaphorical meaning in Western approaches to language, foregrounding how the materiality of sound and voice impacts the weight that analysts ascribe to how words sound.

\section{Conclusion}

Amongst the Arawete in the Brazilian Eastern Amazon, the oporahẽ songs present us with a clear setting in which to investigate the possibilities of sounded phenomena. The oporahe songs work by placing and displacing sounds; by putting a pause between words and placing a syllable where one would expect a pause; by creating silence where there was sound and creating sound in a silent space. It is well known that all translation is radical translation (Mannheim 2015), but working on oporahẽ songs takes the idea of making a translation "foreign" to its limit by attenuating words' referential meaning and breaking them down into a phonological icon of the Araweté language - as if translation meant reducing words to their bare minimum. The journey of the wasp to the end of the world, the dancing bodies that get tense and relax, and the words separated in unusual ways thus convey a specific aesthetic form that, when replicated in written form, reminds us that what people mean when they speak also involves how they sound.

The growing engagement of Amazonian scholarship with linguistic anthropology (Déléage 2009; Cesarino 2011; Gutierrez-Choquevilca 2011) can certainly benefit from broader discussions on what might be called materiality of language (Cavanaugh and Shankar 2017), sonic materiality (Eisenlohr 2018), or even a more restricted notion such as Harkness" "phonosonic nexus" (2014). We must take heed of Webster's call (2016, p. 35), mentioned above, for us to "take seriously the phonetic clothing" of languages. In other words, meaning can also be found in the poetic shape of the sound of words and language is more than reference (Waugh 1980). Along these lines goes Eisenlohr's (2018, p. 50) recent analysis of Mauritian Muslim devotional poetry, an approach that not only sees sonic materiality "as part of signification but also recognizes the possibility of different modalities of meaning in sonic practice."

As many authors have pointed out, for a very long time, referential meaning has been central to Western approaches to language (Bauman and Briggs 2003; Kroskrity 2004) and we should be cautious in looking at non-Western linguistic traditions with a referential bias (Brenneis 1987; Rumsey 1990). However, 
How should we translate the sonic materiality of Araweté ritual singing?

it is still unclear what it means to take seriously the phonetic clothing of a language, precisely because it is difficult to devise an anthropological analysis in which referential meaning is not the basis. Could anthropological analysis of Amerindian societies provide the starting point from which such analysis would emerge (Heurich and Hauck 2018)? The proof lies, of course, in providing precise and detailed ethnographic analysis of linguistic and musical phenomena where central tenets of Western linguistic traditions are challenged and disrupted - such as referential meaning and the shape of words - and build from these examples. In this regard, the oporahe's broken words provide an optimum start.

* Manuscrit reçu en août 2018, accepté pour publication en mars 2020.

Acknowledgements - I wish to thank Julia Sauma, Eduardo Viveiros de Castro, Bruna Franchetto, Pierre Déléage, Andrea-Luz Gutierrez-Choquevilca, Laura Graham, Jan David Hauck, and three anonymous reviewers for their comments on this paper. Previous versions of this paper were given during seminars at CUSAS (University of Cambridge) and at Collège de France (Paris), where I received generous comments from the audience. All the faults that remain, as usual, can only be my own.

The research presented here was funded by the Brazilian National Council of Scientific Research (CNPq) and the graduate funding programme of the Social Anthropology Graduate Program at the Museu Nacional, University of Rio de Janeiro (UFRJ). The paper was written during a British Academy Newton International Fellowship at University College London (UCL).

\section{References cited}

BAUMAN Richard, and Charles BRIGGS

2003 Voices of Modernity, Language Ideologies and the Politics of Inequality, Cambridge University Press, Cambridge.

BRENNEIS Don

1987 “Talk and Transformation,” American Ethnologist, 22 (3), p. 499-510.

Carneiro da Cunha Manuela, and Eduardo Viveiros de CAstro

1985 "Vingança e temporalidade: os Tupinamba," Journal de la Société des américanistes, 71 (1), p. 191-208.

Cavanaugh Jillian R., and Shalini ShanKar

2017 Language and Materiality. Ethnographic and Theoretical Explorations, Cambridge University Press, Cambridge.

Cesarino Pedro de Niemeyer

2011 "Entre la parole et l'image : le système mythopoétique Marubo," Journal de la Société des américanistes, 97 (1), p. 223-257 (https://doi.org/10.4000/jsa.11739). 
Clastres Helene

1972 "Les beaux-frères ennemis. À propos du cannibalisme tupinamba," Nouvelle revue de psychanalyse, 6, p. 71-82.

CIARDI John

1961 "Translation: the art of failure," Saturday Review, October 7 1961, p. 17-19.

DÉLÉAGE Pierre

2009 Le chant de l'anaconda l'apprentissage du chamanisme chez les Sharanahua (Amazonie occidentale), Société d'ethnologie (Recherches américaines, 8), Nanterre.

EISENLOHR Patrick

2018 "Suggestions of movement: voice and sonic atmospheres in Mauritian Muslim devotional practices," Cultural Anthropology, 33 (1), p. $32-57$ (https://doi. org/10.14506/ca33.1.02).

FAUDREE Paja

2012 "Music, language, and texts: sound and semiotic ethnography," Annual Review of Anthropology, 41, p. 519-536 (https://doi.org/10.1146/ annurev-anthro-092611-145851).

Feld Steven, Aaron Fox, Thomas Porcello, and David Samuels

2005 "Vocal anthropology: from the music of language to the language of song," in Alessandro Duranti (ed.), A Companion to Linguistic Anthropology, Blackwell, Malden, p. 321-345.

GaL Susan

2015 "Politics of translation," Annual Review of Anthropology, 44, p. 225-240 (https://doi.org/10.1146/annurev-anthro-102214-013806).

Gutierrez-ChoQuevilca Andréa-Luz

2011 "Sisyawaytii tarawaytii : sifflements serpentins et autres voix d'esprits dans le chamanisme quechua du haut Pastaza (Amazonie péruvienne)," Journal de la Société des américanistes, 97 (1), p. 179-221 (https://doi.org/10.4000/jsa.11724).

Hanks William F., and Carlo Severi

2014 "Translating worlds: the epistemological space of translation," HAU: Journal of Ethnographic Theory, 4 (2), p. 1-16 (https://doi.org/10.14318/hau4.2.001).

HARKNESS Nicholas

2014 Songs of Seoul. An ethnography of voice and voicing in Christian South Korea, University of Chicago Press, Chicago.

HERZFELD Michael

2003 "The unspeakable in pursuit of the ineffable: representations of untranslatability in ethnographic discourse," in Paula G. Rubel and Abraham Rosman (eds.), Translating Cultures, Berg, Oxford/New York, p. 109-134.

Heurich Guilherme Orlandini, and Jan David Hauck

2018 "Language in the Amerindian imagination: an inquiry into linguistic natures," Language \& Communication, 63, p. 1-8 (https://doi.org/10.1016/j. langcom.2018.03.005).

HiLls David

2017 "Metaphor," in Edward N. Zalta (ed.), The Stanford Encyclopedia of Philosophy [on line], Metaphysics Research Lab, Stanford University, 
How should we translate the sonic materiality of Araweté ritual singing?

Fall 2017 Edition, https://plato.stanford.edu/archives/fall2017/entries/metaphor/, consulted 07/04/2020.

Kroskrity Paul

2004 "Language ideology," in Alessandro Duranti (ed.), Linguistic Anthropology, Blackwell, Oxford, p. 496-517.

KUNREUTHER Laura

2014 Voicing Subjects. Public Intimacy and Mediation in Kathmandu, University of California Press, Berkeley.

LEAVITT John

2014 "Words and worlds: ethnography and theories of translation," Hau: Journal of Ethnographic Theory, 4 (2), p. 193-220 (http://dx.doi.org/10.14318/hau4.2.009).

LÉRY Jean de

1580 Histoire d'un voyage fait en la terre du Brésil, Alphonse Lemerre, Paris.

LÉVI-STRAuss Claude

1988 The Jealous Potter, translated by Bénédicte Chorier, University of Chicago Press, Chicago.

Lima Tânia Stolze

2005 Um peixe olhou pra mim, o povo Yudjá e a perspectiva, ISA/Editora Unesp/ NuTI, São Paulo, Rio de Janeiro.

Mannheim Bruce

2015 "All translation is radical translation," in Carlo Severi and William F. Hanks (eds.), Translating worlds. The epistemological space of translation, University of Chicago Press, Chicago, p. 199-219.

Meschonnic Henri

1999 Poétique du traduire, Verdier, Paris.

2008a “The Europe of translation,” Translation Studies, 1 (1), p. 34-40 (https://doi. org/10.1080/14781700701706427).

2008 b “Traduire au XXI e siècle," Quaderns, 15, p. 55-62.

Montoya Antonio Ruiz de

1639 Conquista espiritual hecha por los religiosos de la Compañia de Jesus en las provincias del Paraguay, Paraná, Uruguai Y Tape, Madri, Madrid.

RAPPORT Nigel, and Morten NieLSEN

2017 The Composition of Anthropology. How Anthropological Texts are Written, Routledge, London.

RuMSEY Alan

1990 "Wording, meaning, and linguistic ideology," American Anthropologist, 92 (2), p. 346-361.

SeEger Anthony

1986 "Oratory is spoken, myth is told, and song is sung, but they are all music to my ears," in Joel Sherzer and Greg Urban (eds.), Native South American Discourse, Mouton de Gruyter, New York, p. 59-82.

SolAno Eliete de Jesus Bararuá

2009 Descrição gramatical da língua araweté, Ph.D. Dissertation, Universidade de Brasília. 
STADEN Hans

1974 [1557] Duas viagens ao Brasil, Ed. Itatiaia, Belo Horizonte.

SzTUTMAN Renato

2007 "Cauim pepica - notas sobre os antigos festivais antropofágicos," Campos. Revista de Antropologia Social, 8 (1), p. 45-70 (http://dx.doi.org/10.5380/ cam.v8i1.9558) [orignal version: "«kawewi pepicke». Les caouinages anthropophages des anciens Tupi-Guarani”, in Philippe Erikson (ed.), La pirogue ivre. Bières traditionnelles en Amazonie, Musée français de la Brasserie, Saint-Nicolas-de-Port, 2004, p. 21-42].

VENUTI Lawrence

1995 The Translator's Invisibility. A History of Translation, Routledge, London (https://doi.org/10.4324/9780203360064).

VILAÇA Aparecida

1992 Comendo como gente. Formas do canibalismo wari' (Pakaa Nova), ANPOCS/ Editora UFRJ, Rio de Janeiro.

Viveiros de CAstro Eduardo

1992 From the Enemy's Point of View. Humanity and Divinity in an Amazonian Society, University of Chicago Press, Chicago.

WAUGH Linda

1980 "The poetic function in the theory of Roman Jakobson," Poetics Today, 2 (1), p. 57-82.

Webster Anthony K.

2016 "The art of failure in translating a Navajo poem," Journal de la Société des américanistes, 102 (1), p. 9-41 (https://doi.org/10.4000/jsa.14602).

WeIDMAN Amanda J.

2006 Singing the Classical, Voicing the Modern. The Postcolonial Politics of Music in South India, Duke University Press, Durham. 